\title{
The subduction influence on ocean ridge basalts and its significance
}

\author{
A. Y. YANG ${ }^{* 1,2}$, Y. CAI $^{3}$, C. H. LANGMUIR ${ }^{* 4}$, S. L. \\ GOLDSTEIN $^{4}$, P. MiCHAEL ${ }^{5}$ \\ ${ }^{1}$ Guangzhou Institute of Geochemistry, Chinese Academy of \\ Sciences (*correspondence: yangyang@gig.ac.cn) \\ ${ }^{2}$ University of Chinese Academy of Sciences \\ ${ }^{3}$ Lamont-Doherty Earth Observatory, Columbia University \\ ${ }^{4}$ Harvard University (*correspondence: langmuir@eps. \\ harvard.edu) \\ ${ }^{5}$ University of Tulsa
}

There has long been a clear separation between the chemical compositions of ocean ridge and convergent margin basalts; convergent margin volcanics are relatively enriched in $\mathrm{U}, \mathrm{Pb}, \mathrm{Ba}$ and $\mathrm{Rb}$ and depleted in $\mathrm{Nb}$ and $\mathrm{Ta}$, understood to be a result of fluxes from the down-going plate to the upper mantle. Basalts from back-arc basins (BABB), have intermediate compositions. BABB show the subduction input can escape the arc and become disseminated in the upper mantle. From this perspective it is puzzling why a similar chemical signature does not appear in some MORB. Here we report the first basalts from an ocean ridge far from a subduction zone with a distinct arc signature, akin to BABB, discovered on the Arctic Gakkel Ridge. The most extreme have low $\mathrm{Nb} / \mathrm{U}$ (8-11), $\mathrm{Ce} / \mathrm{Pb}(7-8)$, and $\mathrm{Ba} / \mathrm{Rb}(6-7)$ ratios, much lower than the canonical values for MORB [1]. These samples occur along the eastern volcanic zone of the Gakkel Ridge in the Arctic basin. A new high precision laser ablation ICP-MS data set for Gakkel samples indicates that the BABB influence is pervasive among Gakkel basalts. We construct a BABB index that reveals this influence. Using a new global MORB database that adds more than 1600 new analyses to [2], we show this influence is present as well as in north and south Atlantic and Indian ocean ridge basalts, and almost entirely absent for Pacific ocean ridge basalts. This distribution can be understood as a result of a "subduction shield" that has surrounded most of the Pacific ocean basin for at least the last 180 m.y.. The subduction flux observed at open ocean ridges can be accounted for if $7-10 \%$ of the global slab flux is incorporated into the convecting upper mantle.

\section{REFERENCES}

[1] Hofmann et al., (1986), Earth Planet. Sci. Lett., 79. 3345; [2] Gale et al., (2013), Geochem. Geophys. Geosyst., 14, 489-518. 